\title{
IMPLEMENTASI PROGRAM IPTEK BAGI GURU DALAM MEMBANGUN E-LEARNING DI SMA IBA PALEMBANG
}

\author{
Hastha Sunardi1), Dewi Sartika ${ }^{2)}$, Hendra Di Kesuma ${ }^{3), I m e l d a ~ S a l u z a ~}{ }^{4)}$ \\ 1)Program Studi Sistem Komputer Universitas Indo Global Mandiri \\ 2)Program Studi Teknik Informatika Universitas Indo Global Mandiri \\ 3,4)Program Studi Sistem Informasi Universitas Indo Global Mandiri \\ Jalan Jend. Sudirman No. 629 KM. 4 Palembang Kode Pos 30129

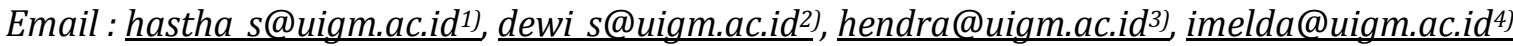

\begin{abstract}
ABSTRAK
Memperkenalkan dan mentransfer pengalaman untuk suatu tujuan yang bermanfaat, khususnya dalam perkembangan dunia pendidikan merupakan kewajiban kita bersama. Bentuk implementasinya dapat dilakukan, diantaranya dengan mewujudkan suatu kegiatan sebagaimana kita kenal Kegiatan Pengabdian kepada Masyarakat. Artikel ini memaparkan hasil kegiatan pengabdian dengan tujuan dapat memberikan manfaat berupa: mengenalkan teknologi pembelajaran berbasis web/android, mewujudkan e-learning sebagai model pembelajaran yang cukup efektif, meningkatkan kualitas peran dan kemandirian bagi guru dan siswa, dan menjadikan elearning sebagai salah satu media interaksi antara guru dan murid. Dalam pelaksanakan menggunakan metode partisipatif dan dialogis yang ternyata memberikan hasil, diantaranya : pihak sekolah, khususnya baik kepala sekolah maupun para guru mengerti dan memahami tentang model pembelajaran e-learning; adanya motivasi yang cukup tinggi dari para peserta (guru) untuk mengimplementasikan e-learning dengan menggunakan aplikasi edmodo, terlihat begitu interaktifnya peserta selama mengikuti pelatihan; peserta yang sebelumnya belum memiliki akun dan belum tahu cara membuatnya, melalui pelatihan ini mampu membuat dan telah memiliki akun dan dengan mengaplikasikan e-learning yang telah dibuat diharapkan dapat memberikan motivasi bagi guru dan siswa dalam berinteraksi, baik di ruang kelas maupun di luar kelas dalam melaksanakan proses pembelajaran.
\end{abstract}

Kata kunci : e-learning, partisipatif, dialogis, edmodo, pembelajaran

\section{PENDAHULUAN}

Berkembangnya teknologi informasi, menuntut kita harus lebih membuka diri agar kita mampu memanfaatkan dan mentransfernya guna mempermudah kita dalam menyelenggarakan aktifitas yang berkaitan dengan teknologi tersebut. Konsep pembelajaran yang baik di era digital ini, membantu kita lebih efisien dan lebih dinamis dalam berinteraksi antara guru/doosen dan siswa/mahasiswa. Terselenggaranya proses pembelajaran yang baik, merupakan aspek penting dari transformasi ilmu dari seorang guru kepada muridnya. Banyak cara dalam proses pembelajaran, apalagi jika mengikuti perkembangan dunia teknologi informasi berupa lahirnya beberapa aplikasi yang dapat kita manfaatkan. Sayangnya perkembangan dunia IT pada bidang pendididkan, tidak diikuti dengan keinginan sekolah untuk mengimplementasi-kannya pada proses pembelajaran di sekolah, yang dikenal dengan istilah e-learning. Pembelajaran merupakan proses komunikasi dua arah, mengajar dilakukan oleh pihak guru sebagai pendidik, sedangkan belajar dilakukan oleh peserta didik atau murid.

Tahapan terpenting untuk menerapkan e-learning, tentunya harus kita pahami dahulu tentang Teknologi Informasi dan Komunikasi (TIK) atau dalam dunia informasi dikenal dengan Information and Communication Technology, ICT. Teknologi Informasi dan Komunikasi, adalah payung besar terminologi yang mencakup seluruh peralatan teknis untuk memproses dan menyampaikan informasi. TIK mencakup dua aspek yaitu teknologi informasi dan teknologi komunikasi. Teknologi informasi meliputi segala hal yang berkaitan dengan proses, penggunaan sebagai alat bantu, manipulasi, dan pengelolaan informasi. Sedangkan teknologi komunikasi adalah segala sesuatu yang berkaitan dengan penggunaan alat bantu untuk memproses dan mentransfer data dari 
perangkat yang satu ke lainnya. Oleh karena itu, teknologi informasi dan teknologi komunikasi adalah dua buah konsep yang tidak terpisahkan. Jadi, TIK mengandung pengertian luas yaitu segala kegiatan yang terkait dengan pemrosesan, manipulasi, pengelolaan, pemindahan informasi antar media. TIK adalah berbagai aspek yang melibatkan teknologi, rekayasa dan teknik pengelolaan yang digunakan dalam pengendalian dan pemrosesan informasi serta penggunaannya, hubungan komputer dengan manusia dan hal yang berkaitan dengan sosial, ekonomi dan kebudayaan. Pemanfaatan tenologi dan komunikasi dalam bidang pendidikan, seperti pemanfaatan komputer dan jaringan komputer memberikan kesempatan kepada setiap pembelajar untuk mengakses materi pembelajaran yang disajikan dalam bentuk interaktif melalui jaringan Komputer. Dari penjelasan tersebut dapat dimaknai bahwa TIK merupakan media yang berupa teknologi seperti komputer beserta jaringannya yang dapat digunakan untuk proses pengolahan dan pemprosesan data yang berguna untuk pemanfaatan berbagai bidang sosial, ekonomi, budaya dan tentunya pendidikan.

Model pembelajaran yang telah diimplementasikan oleh setiap institusi/sekolah tentunya beragam dan kita belum mampu menilai, apakah cukuf efektif dalam transfer ilmu pengetahuan. Salah satu alternatif solusi agar dapat meningkatkan efektivitas dan efisiensi pembelajaran, diperlukan pengembangan suatu model pembelajaran yang inovatif dan kreatif agar proses pembelajaran tidak selalu terkesan membosankan, tidak menarik dan monoton yang dapat menghambat proses transfer ilmu [1]. Oleh karena itu, peran media pembelajaran menjadi hal yang penting untuk diperhatikan. Internet dapat menjadi salah satu pilihan sebagai media pembelajaran yang cukup efektif mengingat internet merupakan alat komunikasi yang murah dan memungkinkan terjadinya interaksi antara dua orang atau lebih dimana saja dan kapan saja. Pembelajaran yang dilakukan melalui media internet dikenal sebagai e-learning [2]. Perlu dipahami bahwa e-learning memiliki karakteristik : (1) memanfaatkan teknologi elektronik, dalam proses pembelajaran siswa dan guru dapat berkomunikasi dengan mudah, (2) memanfaatkan keunggulan komputer, (3) menggunakan bahan ajar yang bersifat mandiri, dapat diakses kapan dan dimana saja, dan (4) mampu menyimpan hasil kemajuan belajar [3]. Edmodo merupakan salah satu media e-learning yang dapat diterapkan sebagai media pembelajaran [4]. Edmodo tidak hanya mudah digunakan, namun juga menyediakan fitur-fitur yang mampu mendukung semua proses belajar beberapa diantaranya unggah materi dengan format bervariasi tidak hanya dalam ekstensi dokumen saja, pelaksanaan ujian yang realtime, pengumpulan tugas dengan batasan waktu yang bisa diatur, voting, saling berkiriman pesan, komentar, bahkan guru dapat memberikan penghargaan berupa lencana bagi siswa/i yang berprestasi. Tidak hanya itu, edmodo juga memungkinkan orang tua dapat mengawasi perkembangan kegiatan belajar mengajar anaknya [6].

SMA IBA Palembang yang merupakan salah satu sekolah swasta tertua yang ada di Kota Palembang dalam hal sarana dan prasarana dapat dikatakan cukup memadai, dimana diantaranya memiliki 2 laboratorium jaringan komputer yang masing-masing berkapasitas 40 komputer, sayangnya belum dimanfaatkan oleh para guru untuk membangun suatu pembelajaran e-learning. Disisi lain sumberdaya manusianya cukup mumpuni dalam mengoperasikan komputer, sehingga sudah selayaknya diperkanalkan suatu aplikasi media pembelajaran berbasis internet, melalui Pelatihan Pembangun e-Learning sebagai Media Pembelajaran Siswa.

Terjebak dengan rutinitas yang harus dijalani dalam mempersiapkan materi ajar, yang merupakan suatu permasalahan yang dihadapi mitra menyebabkan para guru seakan-akan tidak peduli dengan perkembangan teknologi informasi. Karenanya, cukup kita pahami bahwa manfaat dari pelaksanaan pengabdian kepada masyarakat adalah suatu upaya memberikan alternatif solusi terhadap permasalahan pada mitra, karenanya pengabdian ini berupaya mendapatkan manfaat, diantaranya : (1) Mengenalkan teknologi pembelajaran berbasis web (2) Mewujudkan e-learning sebagai model pembelajaran yang cukup efektif (3). Meningkatkan kualitas peran dan kemandirian bagi guru dan siswa (4) Menjadikan e-learning sebagai salah satu media interaksi antara guru dan murid.

\section{METODE PELAKSANAAN PENGABDIAN}

Pendekatan yang dilakukan untuk memberikan salah satu solusi membangun model pemebelajaran yang efektif bagi interaksi guru dan siswa pada sisi mitra, adalah :

a. Pendekatan Partisipatif, yaitu mengajak dan memotivasi para guru untuk berupaya 
mengembangkan diri dengan cara mengenal teknologi informasi yang berkaitan dengan model pembelajaran.

b. Pendekatan dialogis, yaitu semua permasalahan diselesaikan secara bersama oleh dan untuk mereka sendiri, karena itu dalam kegiatan pelatihan ini tim membangun model kebersamaan yang mana setiap peserta secara bebas membentuk grup yang menggambarkan penerapan e-learning dan mensimulasikan penerapannya untuk mataajar yang diajarkannya.

c. Memotivasi guru agar serius dalam mengikuti pelatihan dan bimbingan teknis yang dilakukan.

d. Memberi pemahaman kepada para guru bahwa apa yang dilakukan dan didapatkan dari pelatihan ini, pada dasarnya suatu upaya yang berasal dari kita dan bermanfaat untuk kita juga.

Adanya respon positif dari sisi mitra yang memberikan semangat dalam Pelaksanaan Pengabdian kepada Masyarakat adalah :

a. Menyiapkan tempat untuk kegiatan pelatihan berupa laboratorium jaringan komputer yang cukup refresentatif dengan kapasitas 40 PC, dengan bandwidth yang cukup memadai.

b. Mengumpulkan peserta untuk kegiatan pelatihan dan bimbingan teknis, dan pembimbingan lainnya.

c. Anggota mitra cukup antusias mengikuti kegiatan pelatihan dan mampu mengikuti dan mempraktekkan sesuai dengan materi yang diberikan.

Berikut deskripsi dari setiap pelaksanaan kegiatan yang telah dilakukan oleh Tim dalam upaya membangun model pembelajaran e-learning dengan menggunakan edmodo sebagai berikut:

\section{1) Lokasi Pelaksanaan}

Tempat pelaksanaan kegiatan dilakukan di Laboratorium Jaringan Komputer Sekolah Menegah Atas IBA (SMA IBA), Jalan Mayor Ruslan Palembang

\section{2) Waktu Pelaksanaan}

Waktu pelaksanaan direncanakan dengan persiapan yang sedetil mungkin, sehingga akan memudahkan dalam pelaksanaan Pelatihan Pembuatan e-learning sebagai Media Pembelajaran Siswa di SMA IBA Palembang serta menghindari permasalahan yang akan mungkin terjadi. Hal yang terkait dalam persiapan meliputi:

a. Melakukan diskusi tentang Kegiatan Pengabdian kepada Masyarakat yang akan dilakukan serta materi yang akan disampaikan serta menetapkan jadwal kegiatan.

b. Pengajuan izin kepada Dekan Fakultas Ilmu Komputer dan Kepala LP2MK Universitas Indo Global Mandiri untuk melaksanakan kegiatan pengabdian kepada masyarakat.

c. Persetujuan Dekan Fakultas Ilmu Komputer dan Kepala LP2MK Universitas Indo Global Mandiri menyetujui kegiatan tersebut dengan membuat surat izin pelaksanaan kegiatan pengabdian pada masyarakat.

d. Menyusun Proposal kegiatan.

e. Mengajukan proposal pada Dekan Fakultas Ilmu Komputer yang telah ditandatangani ketua LPPM Universitas Indo Global Mandiri untuk melaksanakan kegiatan Pengabdian pada Masyarakat.

f. Mengajukan proposal pada Kepala Sekolah SMA IBA Palembang Sumatera Selatan.

g. Materi yang dipilih untuk disajikan adalah:

a) E-learning sebagai media pembelajaran

b) Pengenalan dan penggunaan aplikasi e-learning edmodo

c) Mengimplementasikan e-learning edomodo dalam proses pembelajaran

h. Persiapan perlengkapan untuk presentasi

i. Komponen komputer beserta perlengkapan untuk digunakan dalam kegiatan pengabdian kepada masyarakat sebagai berikut:

j. Komputer standar dengan sistem operasi windows

k. Kelengkapan perangkat seperti mouse, keyboard, printer dan projector.

l. Referensi dari beberapa media yang berbasis on-line.

m. Pelaksanaan Kegiatan.

n. Pembuatan Laporan Kegiatan. 


\section{3) Tahapan Pelaksanaan}

Pelaksanaan kegiatan dilakukan selama 1 hari yaitu pada hari Sabtu tanggal 28 Juli 2018, dengan prosedur kegiatan yang dilakukan selama pelatihan adalah :

a. Absensi peserta, dengan mengisi daftar hadir.

b. Pembukaan, oleh Ketua Pelaksana dan Kepala Sekolah

c. Penyampaian materi dengan judul materi pelatihan pembuatan e-learning sebagai media Pembelajaran Siswa di SMA IBA Palembang.

d. Penutupan.

\section{4) Peserta}

Peserta Pelatihan merupakan para guru di lingkungan SMA IBA Palembang dan Kepala Sekolah mewajibkan semua guru mengikuti Pelatihan Pembuatan e-learning sebagai Media Pembelajaran Siswa di SMA IBA Palembang.

\section{HASIL DAN PEMBAHASAN}

Rangkaian kegiatan pengabdian kepada masyarakat berupa pelatihan yang dilakukan di laboratorium komputer yang masing-masing komputer terhubung dengan jaringan internet dengan kapasitas 40 komputer. Adapun bentuk kegiatannya penyampaian materi dalam bentuk presentasi yang terkait dengan model pembelajaran e-learning dan sosialisasi penerapan $e$ learning sebagai media pembelajaran, yakni mengenalkan salah satu aplikasi yang bernama edmodo bagi guru SMA IBA Palembang. Adapun materi yang disampaikan berupa materi penggunaan edmodo yang dapat diakses melalui situs www.edmodo.com, dimana aplikasi dari situs tersebut dapat diunduh oleh guru secara gratis melalui komputer atau perangkat portable yang memiliki sistem operasi android maupun ios. Dengan cara penggunaannya yang cukup mudah dipahami, sehingga para peserta tidak mengalami kendala selama menjalani kegiatan pelatihan.

Langkah awal dalam mengimplementasi edmodo sebagai model $e$-learning, mensyaratkan para peserta telah memiliki akun, namun jika belum ada peserta diberikan pelatihan dalam membuat akun yang dapat dibuat peserta di dalam situs Edmodo. Akun tersebut selanjutnya akan digunakan dalam mensimulasikan model pembelajaran. Selanjutnya setelah semua peserta memperoleh akun, jika peserta disimulasikan sebagai siswa, maka dapat mengikuti kelas dan mendaftarkan kode kelas yang telah dibuat oleh guru mereka untuk tiap - tiap mata pelajaran yang mereka ambil, para siswa juga dapat mengunduh materi - materi belajar seperti buku - buku, maupun gambar-gambar yang telah di upload oleh guru mereka pada masing - masing mata pelajaran. Siswa dapat mengerjakan tugas, kuis, ujian, maupun latihan - latihan yang telah diberikan para guru mereka pada situs $e$ learning tersebut dan siswa dapat melihat nilai mereka masing - masing beserta passing grade nya sebagai tolak ukur kesuksesan mereka dalam menerima materi yang diajarkan oleh para guru.

Jalannya kegiatan pelatihan ini, langsung dipantau oleh kepala sekolah mulai pelaksanaan hingga berakhirnya pelatihan yang diikutioleh 17 peserta yang terdiri guru yang aktif di SMA IBA Palembang. Kegiatan pengabdian kepada masyarakat berupa Pelatihan Pembuatan e-learning sebagai Media Pembelajaran Siswa di SMA IBA Palembang, didokumentasikan sebagaimana terlihat pada gambar-gambar berikut. 


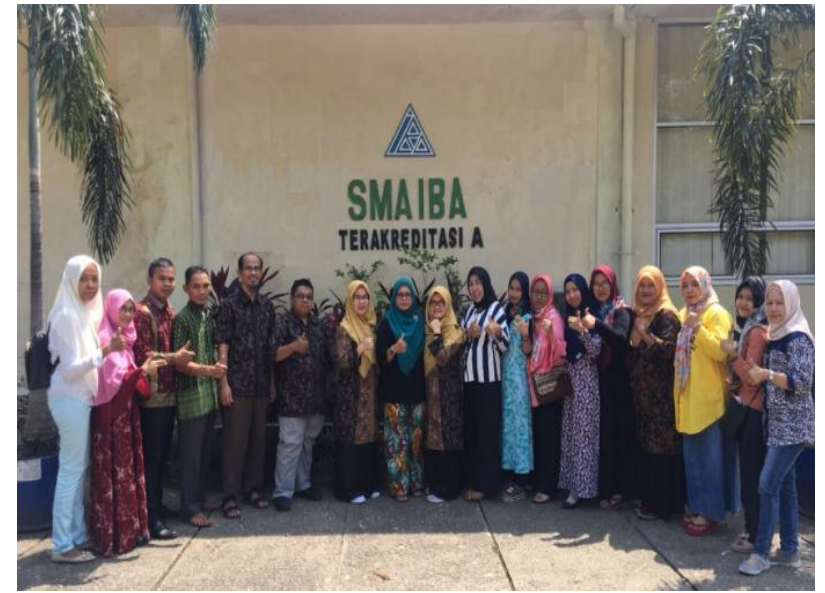

Gambar.1 Foto Bersama Kepala SMA IBA Bersama Tim Pelakasana \& Peserta

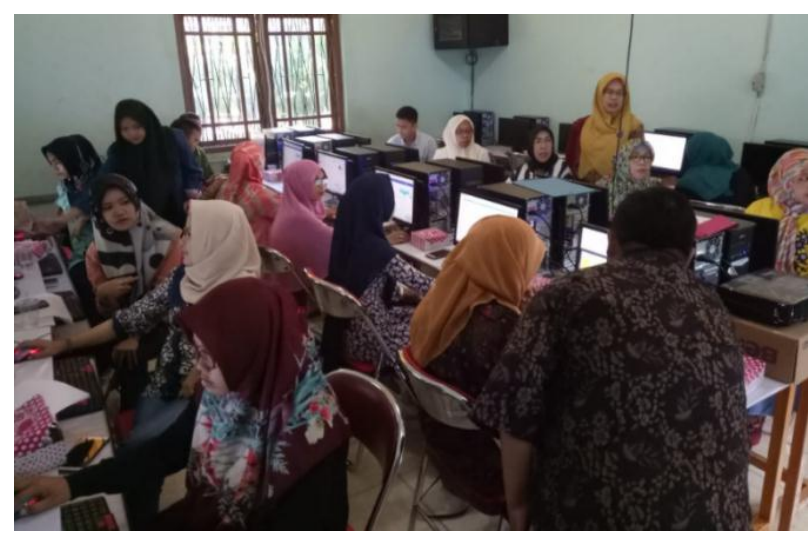

Gambar.3 Peserta Pelatihan Melakukan Diskusi

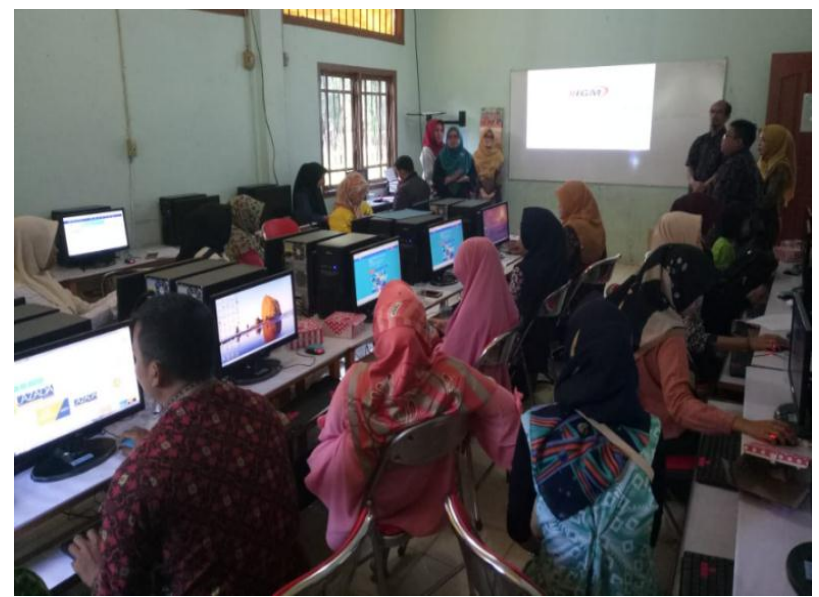

Gambar.2 Pengarahan kepada Peserta Pelatihan oleh Kepala Sekolah

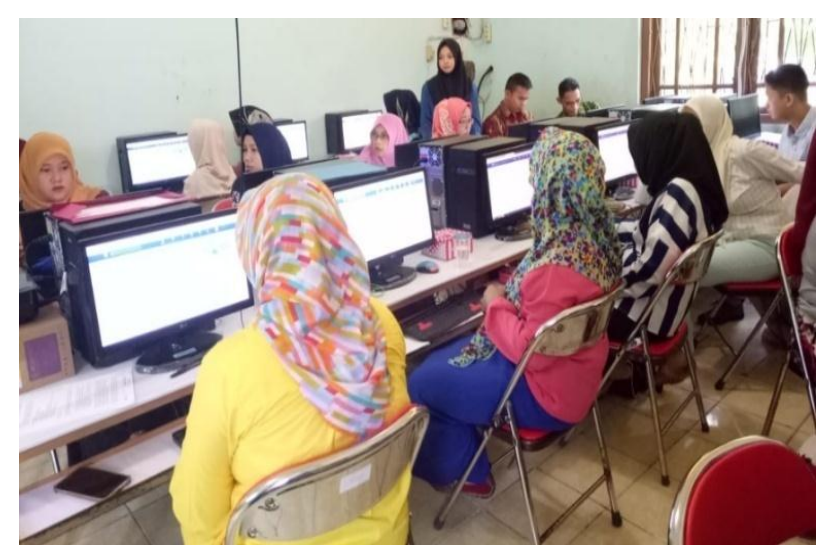

Gambar. 4 Suasana Pelatihan Didampingi Mhs

Kegiatan pelatihan melibatkan 3 (tiga) dosen dan 3 (tiga) mahasiswa sebagai asisten. Kepala sekolah cukup aktif dan terlibat langsung memantau jalannya pelatihan, sehingga kepala sekolah dapat menilai terhadap kesungguhan para guru (peserta) terhadap pengusaan materi yang diberikan. Agar pelatihan berjalan efektif dan tepat sasaran, diberikan materi presentasi dan modul praktikum e-learning dengan edmodo, dalam mempraktekkan terbangunnya proses pembelajaran e-learning dengan aplikasi edmodo, peserta dengan mudah mengikuti tahapantahapan yang ada di dalam modul tersebut. Evaluasi terhadap penguasaan materi, dievaluasi dengan simulasi membangun e-learning sesuai mataajar yang diajarkan guru masing-masing.

Hasil yang diperoleh dari pengabdian kepada masyarakat berupa Kegiatan Pelatihan Pembuatan e-learning sebagai Media Pembelajaran Siswa di SMA IBA Palembang antara lain :

1. Pihak Sekolah, khususnya SMA IBA Palembang, baik kepala sekolah maupun para guru mengerti dan memahami tentang model pembelajaran e-learning.

2. Adanya motivasi yang cukup tinggi dari para peserta (guru) untuk mengimplementasikan e-learning dengan menggunakan aplikasi edmodo, terlihat begitu interaktifnya peserta selama mengikuti pelatihan.

3. Peserta yang sebelumnya belum memiliki akun dan belum tahu cara membuatnya, melalui pelatihan ini mampu membuat dan telah memiliki akun.

4. Dengan mengaplikasikan e-learning yang telah dibuat diharapkan dapat memberikan motivasi bagi guru dan siswa dalam berinteraksi, baik di ruang kelas maupun di luar kelas dalam melaksanakan proses pembelajaran. 


\section{KESIMPULAN}

(1) Peserta memiliki pemahaman tentang model pembelajaran e-learning dengan aplikasi edmodo

(2) Peserta termotivasi untuk mengaplikasikan model pembelajaran e-learning kepada para siswa SMA IBA Palembang

(3) Kegiatan ini dapat meningkatkan kemampuan para tenaga pengajar SMA IBA Palembang dalam membuat dan mengembangkan media belajar menggunakan e-learning.

\section{UCAPAN TERIMA KASIH}

Tim pelaksana mengucapkan terima kasih kepada :

(1) Rektor Universitas IGM, Bapak Dr. Marzuki Alie, SE.,MM.

(2) Dekan Fakultas Ilmu Komputer, ibu Lastri Widyastusi, M.Kom

(3) Para Kaprodi di lingkungan Fasilkom Universitas IGM

(4) Kepala Sekolah SMA IBA Palembang

(5) Para Guru dan Kepala Lab Komputer SMA IBA

(6) Para mahasiswa yang turut membantu Tim Pelaksana.

\section{DAFTAR PUSTAKA}

Azhar. 2008. Media Pembelajaran. no. 1, pp. 1-13. Penerapan Media Pembelajaran dengan Edmodo. 17 November 2016. https://lukvifebrianti.wordpress.com/2016/11/17/penerapan-mediapembelajaran-edmodo/

Georgiev, T. Georgieva, E and Smrikarov, A.2004. M-Learning- a New Stage of E -Learning. Int. Conf. Comput. Syst. Technol 1(1) : 1-5.

Nurseto, T. 2011. Membuat Media Pembelajaran yang Menarik. Jurnal Ekonomi dan Pendidikan 8 (1) :19-35.

Ramadhani. M. Efektivitas Penggunaan Media Pembelajaran E-learning Berbasis Web Pada PelajaranTeknologi Informasi dan Komunikasi Terhadap Hasil Belajar Siswa kelas X SMA Negeri 1 Kalasan.pp. 1-30, 2012.

Sanderson, P, E. 2002. E-Learning: strategies for delivering knowledge in the digital age. Internet High.Educ 5(2) : 185-188.

Yazdi, M. 2012. E-Learning Sebagai Media Pembelajaran Interaktif Berbasis Teknologi Informasi. J. Ilm.Foristek 2(1) : 143-152. 